\title{
Crossing over with the Angel
}

\author{
Alexander V. Kozin \\ Freie Universität Berlin \\ Altensteinstrasse 2-4, D-14195 Berlin, Germany \\ e-mail: alex.kozin@gmx.net
}

\begin{abstract}
This essay is an analytical extension of Roland Barthes' structural analysis of an excerpt from the Old Testament (Genesis 32: 22-32), known as "The Struggle with the Angel". It thus continues the search for "the third meaning" of this enigmatic passage. In this essay, "The Struggle with the Angel" is undertaken in the phenomenological (xenological) register which situates it in the liminal sphere at the crossing of disclosure and concealment. Subsequent semiotic analyses of three visual renditions of Genesis 32: 22-32, Rembrandt's "Jacob's Struggle with the Angel", Sir Jacob Epstein's "Jacob and the Angel", and Marc Chagall's "Jacob Wrestling with the Angel", show the "third meaning" of the passage to be predicated on the foundational relation between naming and facing, pointing to the understanding of "The Struggle" as the face-to-face relationship of love and responsibility grounded in ethics.
\end{abstract}

A little East of Jordan, Evangelists record, A Gymnast and an Angel

Did wrestle long and hard -

Emily Dickinson, “A Little East of Jordan" (Fr145B)

This essay considers an excerpt from the Old Testament, "Genesis 32: 22-32", known as the Struggle with the Angel. This excerpt exudes powerful allure, prompting many scholarly attempts at giving this complex passage exegetic sense. ${ }^{1}$ Among them we find Roland Barthes' structural analysis that dissociates itself from theosophic

\footnotetext{
1 For a list of scholars who attempted an interpretation of "Genesis 32: 22-32", see Desroche (1973).
} 
Biblical interpretations in an attempt to show that the extraordinary potency of the Bible lies beyond its religious import and is grounded instead in the primordial connection to the semiotic universe. As an archetypal text, the Bible discloses the transcendental dimension in its pure uncontaminated state. At the same time, the Bible does not confer this state to the single origin; no singularity should or can emerge from its reading. Its textual purity, notes Derrida, is but a condensate formed by many layers of mythological material of diverse origins. ${ }^{2}$ This is to say that the Bible itself is a semiotic universe par excellence. It thus can lead outside of its telos and into the realm of signitive becoming.

This would-be place of pre-formed possibilities can also be understood as the liminal world. I take liminality in the Husserlian sense, as Zwischen, or new logos, an organization that features connecting nodes but lacks centralization. ${ }^{3}$ Liminality is therefore a paradoxical phenomenon. Importantly, this paradox is not logical but phenomenological, for it is firmly grounded in the living world. We discover limit phenomena in such empirical modalities as children, animals, etc. In addition to life forms, limit phenomena extend to mythical figures, such as spirits and demons. The encounter with limit phenomena is both meaning-creative and self-altering. I therefore suggest that we co-join phenomenology and semiotics in order to investigate Jacob's "Encounter with the Angel" as a limit phenomenon. For this examination, Barthes' analysis provides a conceptual frame that I expand and texture with further material and analyses. The essay's design reflects these intentions. First, I present the excerpt. I continue by giving a condensed summary of Barthes' method as well as his findings. Then, I introduce the phenomenological structure of the alien, explain the alien typology and outline xenology as method. After a methodological orientation is set, I proceed with the analysis based on three artistic renditions of the Genesis episode, Rembrandt's "Jacob's Struggle with the Angel", Sir Jacob Epstein's "Jacob and the Angel", and Marc Chagall's "Jacob Wrestling with the Angel". I end by evaluating the findings from the perspective of semioethics.

2 Derrida argues for the plurivocity of the Bible from the translation perspective in his 1992 article "Des tours de Babel".

3 For an investigation of the in-between of known orders, see Waldenfels (1995). 
(22) And he rose up that night, and took his two wives, and his two womenservants, and his eleven sons, and passed over the ford Jabbok. (23) And he took them, and sent them over the brook, and sent over that he had. (24) And Jacob was alone; and there he wrestled a man with him until the breaking of the day. (25) And when he saw that he prevailed not against him, he touched the hollow of his thigh; and the hollow of Jacob's thigh was out of joint as he wrestled with him. (26) And he said, Let me go, for the day breaketh. And he said, I will not let thee go, except thou bless me. (27) And he said unto him, What is thy name? And he said, Jacob. (28) And he said, Thy name shall be called no more Jacob, but Israel: for as a prince hast thou power with God and with men, and hast prevailed. (29) And Jacob asked him, and said, Tell me, I pray thee, thy name. And he said, Wherefore is it thou dost ask after my name? And he blessed him there. (30) And Jacob called the name of the place Penuel: for I have seen God face to face, and my life is preserved. (31) And as he passed over Penuel the sun rose upon him, and he halted upon his thigh. (32) Therefore the children of Israel eat not of the sinew which shrank, which is upon the hollow of the thigh, unto this day: because he touched the hollow of Jacob's thigh in the sinew that shrank. (Genesis 32: 22-32)

Barthes (1977: 127) begins to analyze this passage with the following goals in mind: "show how the text is unmade, how it disseminates by what coded paths it goes off". The name of this analysis is indicial. This is to say, it is a form of sequential analysis that pursues the ways of metacategories through their sequential production. The search for meta-categories begins with two kinds of units: the state of the character (i.e., indice) and the state of their actions (i.e., epithet). The correspondence between the two produces meta-meaning. Barthes' main focus is not the metacategories themselves, however, but their disseminating potential. From this perspective, his analysis proceeds progressively, that is, it seeks to identify those sequential positions and content categories that are responsible for "the abrasive frictions, the breaks, the discontinuities," in sum, various ambiguities of interpretation (Barthes 1977: 140).

For the key sequences in this passage Barthes takes: (1) the Crossing, (2) the Struggle, (3) the Namings. A close examination of Sequence (1) produces the first indetermination. Correctly, Barthes points out that the passage does not tell us whether the encounter with the Angel began before or after the crossing. This determination is essential, however, for the reading of the text: the character's position means that the struggle could be either for the right of passage or as the price for passage: "(23) And he took them, and sent them over the brook, and sent over that he had. (24) And Jacob was alone; and there 
he wrestled a man with him until the breaking of the day". The friction between the two meanings creates structural ambiguity, puts the text in suspension. The second sequence, The Struggle, is equally ambiguous. The personal pronoun "he" is placed in the text in such a way as to refer to both the Angel and Jacob: "(25) And when he saw that he prevailed not against him, he touched the hollow of his thigh; and the hollow of Jacob's thigh was out of joint as he wrestled with him". The position is remarkable in its narrative potency: observing fighting men, can we say for sure who dealt what blow to whom? The movement is chaotic, it changes the course too quickly for an ordinary eye to understand. Would this opacity not be exacerbated manifold in the case of an omnipotent entity such as God? But, then, again, can we say for sure that it was God? Or, rather, was it God in the Angel's body, or was it the Angel who represented God? This ambiguity is crucial for the understanding of the extent of Jacob's strength and therefore his ability to win.

According to Barthes (1977: 135), the markings might explain God's or Angel's pseudo weakness, for it was employed as an item of exchange for what follows, the Namings: "The mark is a creative of meaning." And not only meanings, we might add, but new subjectivities. God marks Jacob so that he knew that he was chosen, submitting Jacob to his league. Importantly, the touch of God had no violence in it: God's marking should not be confused with branding. God only touches to bless. But, the blessing came before Jacob had requested for it. What he received instead was a new name: "What is in question in each naming is a change - of place, parental line, name, alimentary rite [...] a transgression of the rules of meaning" (Barthes 1977: 136). It is there, in the detachment of meaning from its signified that Barthes finds the text's signifiance. The frictions, the breaks, the discontinuities - they are all paramount to the text as they make for the combinatory effect of binding. For us, the realm of significance serves as the point of departure into the realm of xenology. My task for what follows is to connect the disseminations of significance with the ethics of liminality. 


\section{Xenology}

There are problems emerging here of creating concrete understanding and $\mathrm{mu}$ tual understanding - to somehow accomplish a making home of the alien, as if it were home. Of course, there is also the question of the limits of such knowledge and the question of justifying the idea of complete understanding.

No doubt, the term xenology is cumbersome. It is made of two equally loaded components, xenos and logos, and each of these components carries much historio-philosophical weight. For now, I would only like to state that xenos refers to the unfamiliar and unknown, in short, - the alien, while logos to word as in speech but also in reason. One may say that xenology deals with the experience of the alien. I thus approach the issue of the alien, the encounter with the alien being, and the ethics of being-with-the-alien in the phenomenological register. Below, I would like to explain xenology in terms of its philosophical roots first and then in terms of its methodological implications.

When Husserl refers to the concept of the alien in his 1931-1933 manuscripts, he introduces it through two senses: (a) as transcendental structure, and (b) as empirical modality. Since Husserl's own writings on the intersubjective dimension of the alien are sketchy and unsystematic, interpretations are required. According to Steinbock (1995), the structure of "alienworld/homeworld" is one of the three transcendental structures, that is, it is foundational for the constitution of all experience. The other two mentioned by Husserl in various later texts are "earth-as-ground," "world-as-horizon." Although the three structures are intimately connected and can be considered co-determinate, the explicitly intersubjective dimension of the alien as well as the physical limitations of my investigation force me to focus on the last structure. Briefly, the relationship between the homeworld and the alienworld is a relationship between what belongs to the recognizable "home" or sphere of ownness and the experience of the unrecognizable "alien" that encompasses everything that is constituted by a world other than my homeworld. The homeworld is therefore a parallel structure that 
co-constitutes the alienworld, and it is through this co-structure that normatively significant lifeworlds are constituted. In sum, the structure alienworld/homeworld is transcendental and non-foundational, which makes the relationship between the home and the alien an overreaching model for understanding the genesis of all, but especially social experience.

The socio-symbolic dimension of the alien is embodied symbolically in alien cultures and empirically in the Alien being. ${ }^{4}$ For Husserl, the original category Alien is comprised of children, foreigners, and animals. In this list he sometimes includes the savage and the madman. All these types are abnormal in a sense that they respond to the paradoxical mode of givenness: the alien is "accessible in genuine inaccessibility, in the mode of incomprehensibility" (Husserl 1973: 631). This makes us experience the Alien as a heterogeneous being, that is, completely on its own, reflectively outside of our constitutive comprehension. Unlike rational and culturally familiar adults, Alien types prevent incorporation into the sphere of ownness. We no longer experience the world as children; nor can we experience it as the insane do before actually having got mad; likewise, foreign modes of constitution irrevocably separate us from other cultural subjects. Coming from and with a world of their own that is delimited from our own world, Alien types are shadowy or, to put it in phenomenological terms, liminal phenomena. It is for this reason that Husserl calls them Limes-Subjekte. Limit-Subjects help us co-generate our world as always already evolving. One way to understand our experiences of these generative encounters, we bring them out as narratives. According to Steinbock (1996: 219), "mythical narratives attempt to give an account of a 'genesis' that is genetically impossible to know, but generatively possible to experience in the generative density of a tradition."

It is at this point that we can usher the figure of the Angel into the Husserlian typology. As a Biblical personage, the Angel can be experienced as both the liminal subject and liminality itself. Together with other alien types, it is equally incomprehensible and inaccessible. This is not to say that the Angel is in/significant. In the Bible, a lot of times, the Angel performs as a harbinger of God's will, a messenger.

\footnotetext{
4 To be consistent with the common convention used to distinguish Other and other, I consider Alien (with a capital "A") to be the alien person. The use of alien (with a lower case "a") refers to alienness generally.
} 
In this respect, the etymology of the term "angel" in instructive: the Hebrew word for angel is mala'ak; its meaning is analogous to the Greek angelos. In both Hebrew and Greek, the term means "the one announcing a message". There are other terms and functions for "angel" in the Old Testament, however: "Seraphim", "Cherub", and "the son of God". In Hebrew, Seraph means "flame." The term is rare: we encounter it only in Isaiah 6:2 and 6. From this definition, we can derive the meaning of angel to be the designator for the possibility of speech, its comprehensibility. In the phenomenological terms, the Angel would be the givenness of speaking for a reason.

The second meaning of angel is more common. A wide variety of cultural products accept Cherub to be an angel who is a living being. The cherubs that Ezekiel saw in his vision had four wings and faces like lions, bulls, eagles and human beings. They had human hands, but their feet were like hooves. In general, cherubs are described as "strange to look at" (Ezekiel 1: 4-14). They too, like those Isaiah saw, "shone brightly, like burnished bronze" (Revelation 4: 4-8). The third term that is generally thought to refer to angels is found in only a handful of places. It is usually - though not always - translated as "the sons of God". How to understand the term is a topic of great controversy, especially in Genesis 6: 1-4, where the sons of God had sex with the daughters of men begetting the Nephilim who, although deprived of immortality, had prolonged lives; they were considered to be wise and powerful heroes of the ancient breed. This kind of an angel is an archetypal hero, the embodiment of goodness and the defender of faith.

As an imaginary entity, the angel necessarily features a set of attributes that stabilize its being for us. In turn, these attributes are derived from the corresponding functions. If we reduce the already reductive angel typology to a set of most basic features, we will have: strange; god-like; erotic. All these attributes are connected to the Angel's relation to the inhuman world. For the sake of conceptual consistency, I will call this world the angel world. The relationship between the angel/alien-world and the human/home-world is based on the communicative encounter. After all, the Angel's job is to announce God's will. Yet, the ways of announcing the holy words defies the human language. The Angel speaks but it speaks the language of symbolism that codes out innermost experiences, the ones that can be called pre-subjective, or, following the Husserlian terminology, 
primordial. The Angel thus joins the paradox of original non-originality: it speaks but none can understand the language. The Angel's speaking is inaccessible to our comprehension except, as the Christian tradition goes, in the mode of utter belief and revelation. If we want to understand this mode in the phenomenological terms, we might want to solicit help of Giorgio Agamben (2003: 114), who called glossolalia an aporia of an absolute desubjectification and "barbarization" of the event of language, in which the speaking subject gives way to another subject, a child, angel, or barbarian who speaks "into the air." At the same time, despite the Angel's inaccessibility, the asymmetrical relationship between the two co-joint worlds remains cofoundational: the Angel needs the encounter with Jacob as much as Jacob needs it. At this juncture we can ask a phenomenological question, Shall we not try and understand what the encounter with the Angel means by examining the how of this encounter? In the following two sections I suggest that we answer this question by first investigating an encounter with the alien and then turning to the imaginative representations of Jacob and the Angel.

\section{Encountering the Alien}

Phenomenologically speaking, the encounter with the alienworld occurs first on the threshold, at the boundaries, or in-between the normative and, therefore, familiar experience, and the experience that comes as a wave of incomprehension, overpowering us too quickly and too deeply to make it possible to distinguish amidst all this alienness a specific Alien. In the wake of this experiential conflict, the Alien cannot be singled out even in reflecting back. In vain one will be identifying the features that could turn the Alien being into an object of investigation. The experience of an Alien being is only possible in and through the experience of alienness that extends beyond a particular physical form or a specific, although non-recognizable (at first) behavioral pattern. No extrapolation of the alien from the alienworld is possible without losing the alien in the homeworld as the experiential base. "Limits of a home emerge through the appropriation of a home, and the alien is liminally encountered as such by being delimited from the home as alien" (Steinbock 1995: 180). 
Yet, despite the level of its absorption in a radically different culture, the alien is never completely dissolved. It stays in us: "...we, as home, are already becoming alien through liminal encounters without having to take "foreign qualities"" (Waldenfels 1996: 254). Always murky, the alien lurks in the shadow, between what is completely familiar and what is completely unfamiliar. This non-specific world of liminal givenness is non-recognizable; however, it is not dark either. It glimmers as a beacon, cutting through the space that, out of fright, we commonly fill with nothingness, or endow with the power of negation. However, this space of the in-between is never fully filled. It comes from the darkness of the absolutely alien but never reaches the light of the same, remaining at the edge of darkness, crepuscule, or twilight. The twilight, as a place of meeting the unfamiliar, has its own order: "We encounter the alien as something that can not be said or done within our order. The extraordinary makes its appearance as an order existing elsewhere" (Waldenfels 1996: 115).

Although indeterminate as an order, the alienworld can be experienced in its empirical modalities. We therefore encounter it first as those modalities, although in a radically different way that if we would have encountered our home-comrades. According to Depraz (2001: 169), "infants, animals, the insane, and aliens are subjects in the full sense because they are from the very beginning always already intersubjective subjects". The overreaching concept for the alien types is asymmetry: the relationship with the alien is irreversible. The inaccessibility to full understanding puts the alien on the side under the homeworld not unlike the way the slash sign separates and unites the two concepts: home/alien. Since the homeworld holds ontological priority over the alien world, it provides the base for the understanding of what comes "next". In turn, this asymmetry results from the process of self-differentiation: the self or soul as a home that begins from the radical difference. The alien constitutes itself by self-differentiation, that is, the alien arises from the process of self-alienation. "Alienness then does not proceed from a division but consists in a division" (Waldenfels 1990: 21).

Depraz (2001: 172) argues that the intimate nature of the home/ alien asymmetry allows for empathetic understanding of the Alien. Lived empathy is "grounded in a much more passive and primal experience lying in our lived bodies." Thus, through intercorporeal coupling, the alien is connected to the home. The way of coupling is 
different for the four aforementioned types, however. The child with his or her pre-formed way of connecting to the world is also presubjective. According to Depraz (2001: 175), "it is a passive, latent, driven, affective and blind intentionality." In other words, infancy is a condition of indeterminacy. It comes from the overwhelming experience of firstness. It also opens a way into vulnerability. The same opening is exacerbated in the case of the animal. It evokes the original touch, so to speak of, the experience before it turns into a sedimentation evoked and then confirmed in reflection. In contrast to the child, the animal is inter-animal. Reflection is not given to an animal. This allows the animal to connect to other animals completely.

The same characteristic prevents an animal from connecting to human beings. It is separated from the humanworld completely. This might also explain the non-subjective status of the animal. This is why, Waldenfels separated the animal from other Alien categories and put it "in the shadow". In Husserl's words, "the animal is most wondrous". If the child and the animal are characterized by embodied passive association, the insane is self-divided. Its temporal inchoate being produces "a paradoxical closing-up effect, as a kind of radical solipsism" (Waldenfels 1996: 177). This fact brings the insane au contraire to both the child and the animal. It is the most imaginative case of the Alien. In an empathetic move, we can imagine becoming insane; a lot of times, we think we are. Yet, once we become one, we can no longer connect to others. This is why the insane alien is the most inaccessible. The foreigner is closest to us as his/her alienness is communal, historical, communicative. They are, according to Husserl (1973: 13), "a generative unity, and thus, a primordial language unity/unity of language and language customs."

At this point, we might want to ask, What consequences does the encounter with the alien has for our experience? The answer to this question brings us to ethics. If we cannot respond to someone in a manner that yields an expected response back, we must resort to a transgression: not only we need to transgress our own world, we must transgress the world of the Other. The end-result of this ethics would be to let our "normativity to be disturbed by the abnormal all the time" (Waldenfels 1996: 122). Staying at home and hosting the alien would mean to take the alien as the alien, appropriate it in the image of the same. In contrast, transgression is grounded in responsivity, a turning-toward. This type of resistance is non-violent, non-separatist, non-unifying, and, in that sense, 
non-appropriative. It paves a route that reaches the alien by "crossing over from within" (Waldenfels 1996: 49).

When we insert an alien original inside our modes of communicating with it, we respond for the Alien and not toward. To respond to the Alien from within means to recognize the one-sided origin of our normative world, and, using this acknowledgement as a point of departure, respond to the Alien in-between the comprehensible and the incomprehensible. In performing the response, the respondent enters the process of alien-becoming, with all Alien facets engaged. The vulnerability of a child, the sound and the fury of the madman, the uprightness of the foreigner, and the shadowy figure of the animal, all these alien qualities come to stipulate the encounter as a whole. Empathetic embodied passivity and subjective asymmetry allow for the encounter to take place.

Now, we can return to the analysis of Genesis with a new map and direction. The new focus is on the encounter with the angel as the alien. Phenomenologically speaking, what the Angel does is in how it appears or is made appear. As an Alien type, the Angel is passive, yet seductive; vulnerable, yet powerful; incomprehensible, yet exceedingly clear. This internal asymmetry reflects the external one: the Angel always hovers over, and it always stands under. Although the Angel is not substitutable for a man, coming from the twilight together with other alien types allows the Angel to assume a familiar form. As something that has no recourse to what has happened, an imaginary event of encountering the Angel emerges and develops in the shadow of our experience. The shadow gives the event, including its main content, and, at the same time, it hides or obscures this very event in the texture of what seemingly does not belong to it. This dual function, that of concealment and that of disclosure, makes the mode of angelic appearance most significant.

This mode of appearance is defined by Barthes as "the third meaning". For Barthes, the third meaning gestates outside of the obvious symbolic gesture, in signifiance. Barthes calls this meaning obtuse; it is a meaning that prays on uncertainty. Ambiguity is its mode of showing: "The characteristic of the third meaning is to blur the limit separating expression from disguise, but also to allow that oscillation succinct demonstration - an elliptic emphasis, if one can put it like that, a complex and extremely artful disposition (for it involves a temporality of signification)" (Barthes 1977: 55-56). 
Another way of putting it: the obtuse meaning is the signifier without signified. Therefore it is located outside of language. However, by showing itself in a particular textual field the third meaning enunciates. The work of enunciation becomes particularly strong in the case of intersemiotic translation, in other words, when the third meaning travels from the original field into another semiotic system, such as visual imagery.

In his analysis of filmic and photographic image, Barthes locates the third meaning on the periphery of the forwarded imagery, what he calls metonymic montage. Eisenstein's black and white films are perfect examples of forwarded content. They announce meaningful symbols as they advance one after another like condensed projectiles, accumulating into a critical mass of a single conotatum: "greed", "pain", "now is the time". In contrast to the obvious symbolics, obtuse meaning disperses the metalinguistic (critical) interpretation that offers itself for a quick consumption into broken shards of meaning. These shards no longer define the whole but arise from it carrying their own interpretative weight. With the film that happens as an unrolling stream of imagery, one can barely discern their work. Once taken out, stopped, however, those stills reveal their independence: a barely discernable fly on the face of the tyrant," a pair of hastily repaired glasses on the face of the running woman, these details are in fact inaccessible accessibilities.

In the following analyses I attempt to discern the third meaning in visual representations of "Genesis 32: 22-32". Three artistic works figure in the analyses: Rembrandt's "Jacob's Struggle with the Angel," Sir Jacob Epstein's "Jacob and the Angel," and Marc Chagall's "Jacob Wrestling with the Angel." The selection is not haphazard: from a number of visual interpretations of this passage, the selected three "stills" are singled out because they deviate from traditional renditions of what has happened at Jabbok. ${ }^{5}$ In addition, the focus of all three works is The Struggle, the central sequence in Barthes' typology. The question that I pursue here is, How is the struggle with the Angel given as the encounter with the alien? In view of the phenomenological nature of this question, in my interpretations I will rely heavily on the description of both the encounter with the artistic work and the encounter as a theme of this work.

5 Other well-known interpretations come from Moreau, Gauguin, and Redon (for more, see Singletary, 2004). 


\section{“Jacob's Struggle with the Angel” by Rembrandt}

The Staatsgalerie in Berlin gives the piece (Fig. 1) a prominent position. It is hanging in the Hall No. 5 next to two other Rembrandts and some other Baroque art. The painting's placement is significant in at least two respects: first, it is being given as a period piece; second, it contrasts with the neighboring full-size pieces. As a fragment, Rembrandt's depiction is a perfect still. It is thus extremely selective and economical as to the represented details. A master of psychological portrait, Rembrandt found his artistic fame in the humanist approach to his subjects. The eyes, the face, the hands, all these attributes of human personification were the node of his utmost attention. The unflattering realism with which he portrayed his wife Saskia testifies to this uncompromising preference. It was so strong at times that he would be accused of moral turpitude and proliferation of the abominable. His Biblical paintings are especially notable in this regard. Few of them are stylized to the point of disguising both the contemporariness of the exhibition and the individualization of the character. This dual tendency is exhibited in the choice of the costumes, lighting, background, and figure arrangement.

In his fragment of the struggle, Rembrandt uses the same realistic signature. Rembrandt's strokes are not fine and miniscule but deep, saturated, and broad. His characters reflect the techniques: they are as strongly and as broadly outlined. Assisting each other, form and content produce a singular image that nonetheless allows multiple interpretations. In the painting, we don't see Jacob's legs, but he appears to be wearing a peasant shirt. A closer examination shows that his shirt is in fact a robe, a traditional garb of the housemaster. Judging by the way Rembrandt depicts his body, Jacob is very strong. His physique exhibits inhuman strain. The direction of Jacob's force creates a contradiction, however. At first, it appears that Jacob is straining under the weight of the Angel, but this is only if the Angel has any weight. On the contrary, he does not seem to have any mass; nor is he struggling. He appears to be suspended, in repose. The Angel does not seem to be engaged in combat. He is a subtle and graceful creature, so, his hold on Jacob is light, almost effortless. His facial expression is that of tenderness and sadness. It appears as if while Jacob is struggling with the Angel, the latter is being supported by Jacob, who is expected to carry him some place safe. 


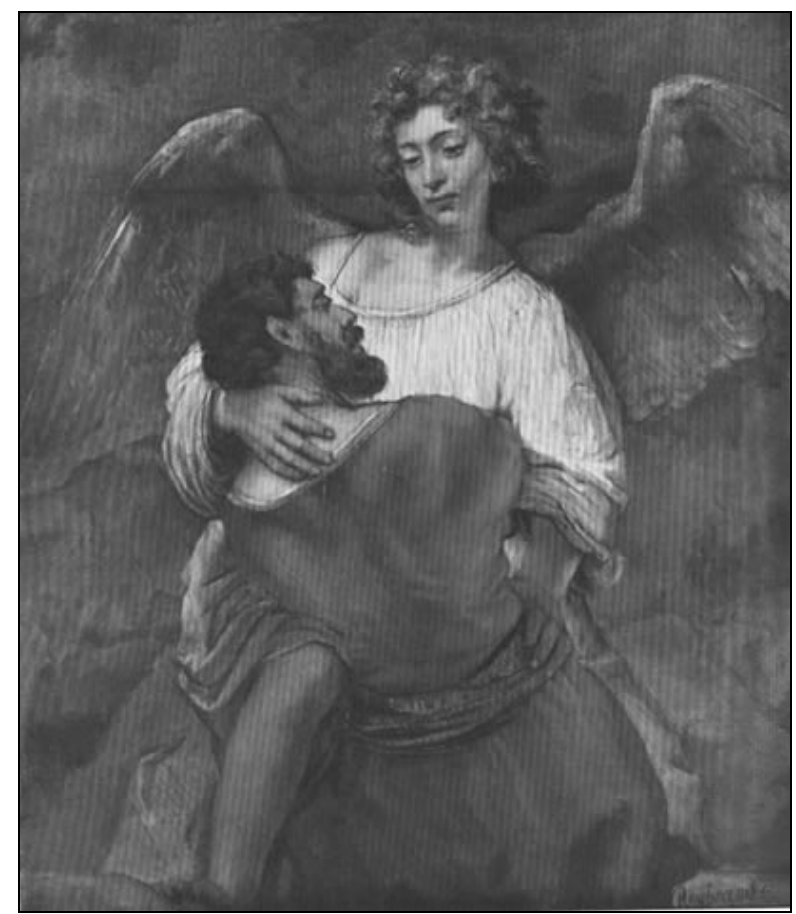

Figure 1. "Jacob's Struggle with the Angel” by Rembrandt.

Yet, it would be a mistake to confuse the Angel's grace with a lack of power. His power, however, is entirely different from Jacob's powerful embrace. While Jacob is being busy with his struggle, looking away, the Angel is looking at the Man with adoration. The Angel's leg that curls around the man's waist is not hurting Jacob, it is caressing him. So are the Angel's hands. The Angel's touch reveals itself as caress. The power of caress comes from Eros. The contrast between the non-struggling erotic Angel and Jacob creates an uncanny and marvelous impression, or face. It also reformulates the asymmetry in the relationship between the Angel and Jacob. What the Angel gives to Jacob is love. Love is not given without struggle. The struggle has nothing to do with earning love, however: its significance is not that far removed from the embodied realm, and we discover it in the next work. 


\section{“Jacob and the Angel” by Sir Jacob Epstein}

This monumental statue (Fig. 2) stands in the middle of the Gregorian Hall on the second floor of the Old Tate Gallery in London. It took Sir Jacob two years to carve this man-size sculpture from a block of alabaster. When it was moved to Tate, the decision was made to have it as a central piece in the connecting rotunda. The statue's placement has an obvious pragmatic side, for it allows for multiple perspectives; the statue's position as a symbol bears a different significance. At the site of the museum, the work sits in the center as if to gather other pieces together. It is a node in a system of visual and aesthetic relations. A visitor encounters the piece in the mode of dissociation while in travel from one hall to another. Even if it may not intend to take the traveler by surprise, it does so. It therefore satisfies and emphasizes the textual reference. It appears right at the time when one is about to break her connection to the aesthetic and sink back into the mundane attitude, thus re-experiencing a return to the ordinary. Is it when he was crossing the river, carrying with him the narrative of hardship that Jacob was surprised by the Angel? And when the Angel appeared, did he offer an introduction? The Biblical narrative brings the reader straight to the struggle, without previewing it by the scene of appearing. We cannot tell from the text where the Angel came from. This apparent omission is not an omission, however. Angels do not appear. They reveal themselves. We may suggest then that the struggle begins at the moment of revelation. Cut off from the moment of its initiation, it is reduced to a specific binary configuration: Jacob - Angel. This single configuration forms a still. Sir Jacob's artistic creation manifests it. At this point, we might want to examine the still, the statue itself. 


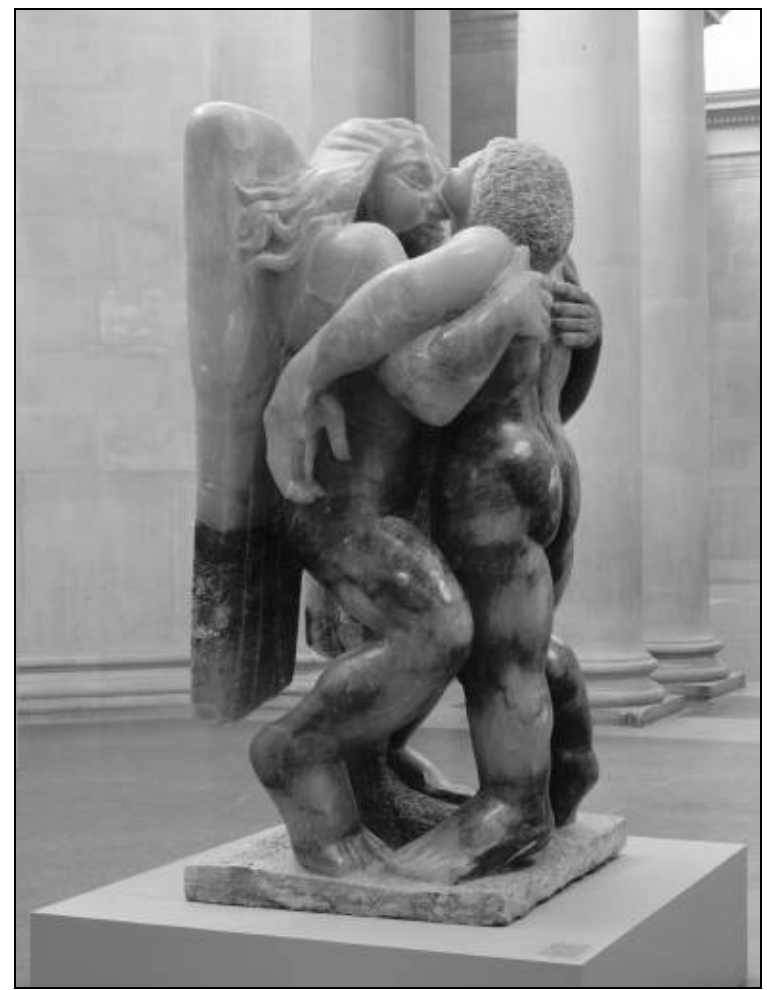

Figure 2. "Jacob and the Angel" by Sir Jacob Epstein.

The statue clearly depicts a struggle. As a still, it captures the struggle under way in a moment of its fading. The frozen moment discloses itself as embrace, and, as in any embrace, the two people hold each other, or one can hold the other. In "Jacob and the Angel" the Angel is holding Jacob. Not just holding but keeping him from falling down. Jacob's body is limp, lifeless. His right leg is wounded from the Angel's touch. Without the Angel supporting him, he would fall down for sure. A giant next to Jacob, the Angel lowers himself to Jacob's height. In doing so, he contorts his powerful body to straighten Jacob's impassive one. In this position the Angel is revealed as Zwischen, the in-between, or liminality itself. Standing face-to-face with Jacob, the Angel is protected by his wings attached to his back 
like two slabs or two halves of a door. What door, we might ask? Could it be a door to Heaven? The Angel has his back, his wings, the divine gift, in the way. Could it be so that the Angel was about to open the door for Jacob? The wings are the vulnerable spot for the Angel: "The Angel dies when you break the Angel's wings," wrote Brecht. The Angel's wings as the site of vulnerability re-introduce the theme of crossing over as the theme of the opening/ closing. The wings are the Angel's retreat: "let me go, for the day breaketh." He comes as light; he goes with light. The struggle has ended: Jacob has earned his passage by submitting to the vulnerability of the Angel, his face, his embrace and his care. While, the Angel is looking straight at Jacob, the man is looking up, searching for God. Frozen in the moment of Embrace, the artistic still arrives at an interpretative singularity: wrestling with the angel was not about resisting; it was rather about submitting and falling into the hands of God. The embrace redefines the asymmetry of the encounter: Jacob's crossing is falling, and the Angel is there to catch him. At this point, we are entitled to ask, What is the Angel doing by caressing Jacob in his powerful embrace?

\section{“Jacob Wrestling with the Angel” by Mark Chagall}

Chagall's painting (Fig. 3) is hanging on the walls of Museé national Message Biblique Marc Chagall in Nice next to other paintings by Chagall, some of which also depict angels. There we find "the Fallen Angel" and "Jacob's Ladder". "The Struggle with the Angel" therefore comes not as a single piece but comes connected with other Biblical paintings through the artist's style given in variation and through a thematic unity. In the context of the museum, it suggests a consistent reading that takes the reader outside of the painting itself. The colors, the composition, and the history of Chagall's work connect it to both Russian expressionism and French cubism. His association with Delaunay and Modigliani becomes transparent once the reader of his works is given an opportunity of visiting other halls in the museum. 


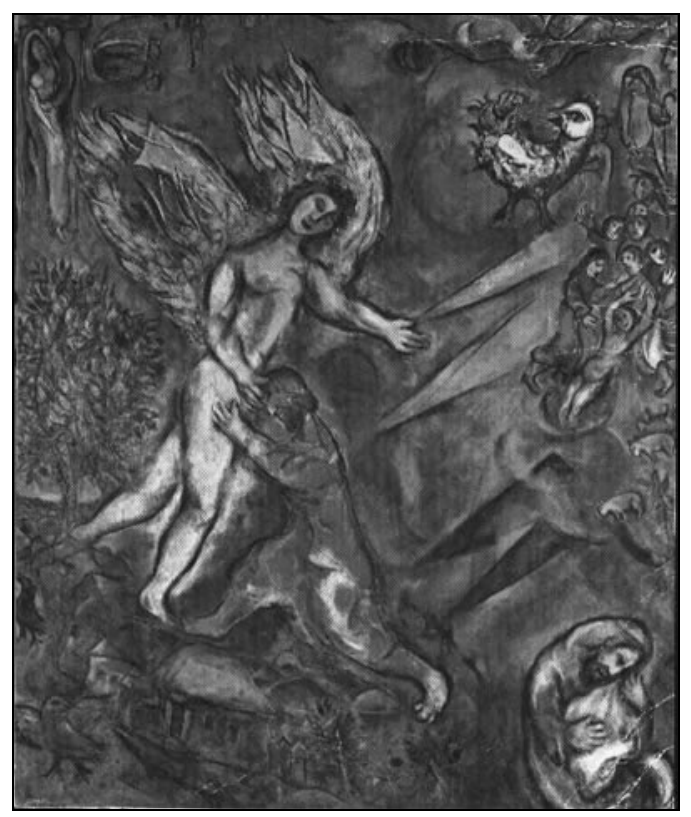

Figure 3. "Jacob Wrestling with the Angel" by Mark Chagall.

The generative side of Chagall's personal artistic style coincides with his interest in Jewish culture and religion of which he was, selfadmittedly, a devoted follower. His Jewish heritage translates into explicitly religious motifs in graphic arts, designs for opera and ballet, ceramics and stained glass windows. In addition, his visual arts exhibit the kind of humor and fantasy that have invited critics to suggest that he draws deeply on the resources of the unconscious. Indeed, Chagall's personal and unique imagery is often suffused with exquisitely subtle sujets. Yet, all these influences should not be taken for the foundation of sense that illuminates his work. As Barthes (1977: 148) argues, the modern art defies historiographic or biographical interpretations because "it is made of multiple authors, multiple voices". What singles a specific text out of this multiplicity is the author's performance. It is with this suggestion in mind that I am going to read Chagall's "Jacob Wrestling with the Angel". 
As compared to Sir Jacob Epstein's sculpture whose three-dimensionality may count for a context of its own, Chagall's painting comes with an imbedded context. Unlike Rembrandt's still, it preserves the main line of the story by re-presenting the key elements of the story: the creek, Jacob's family, and the nocturnal deep density of the encounter: "And he rose up that night, and took his two wives, and his two women-servants, and his eleven sons, and passed over the ford Jabbok." In contrast to Rembrandt, whose work he surely knew, Chagall staged the battle in such as way as to have it be witnessed by the Jacob's family. He thus interpreted the passage from Genesis in a sense different than the intended one: Jacob was alone when he began to struggle with the Angel. He was also struggling alone. From his perspective, he was alone. But, at the same time, he was being witnessed. The subtlety of this discrepancy is emphasized by the audience's position. The other characters are placed in the upper right corner of the painting. By making this choice, Chagall detaches them from the scene that develops in the lower left side corner: the struggling Jacob trying to overpower the Angel. The creek separates the wrestlers and the audience. By this montage, Chagall resolves the ambiguity discovered by Barthes: Jacob is on the other side of the Creek.

With great force and determination, Jacob is trying to push the Angel to the edge of the painting, over the creek, away from his people. In the meantime, the Angel, somewhat immobile and inert, doll-like, is hanging high up in the air, over Jacob. There is a certain rigidity about the Angel's figure, even deadness. He is not resisting Jacob; he is simply hanging lifeless. It is not clear from the painting if Jacob had lifted the Angel up in the air, or the latter lifted himself. The Angel's wings are on fire, spread widely. Unlike Jacob's determination, the Angel's disposition is indetermination given as weightlessness and flight. The Angel exercises this power to point to those people who came with Jacob and are now standing on the other side of the brook. Pointing is the other side of naming. By pointing, the Angel gives Jacob the direction, thus disclosing his own mission: he is there to show the way. The moment is transforming in both literal and figurative sense. It is a moment of ethical reversal. Hovering over Jacob, the Angel is pointing to his people as if forcing Jacob to turn back, to return to the world of his own. 
In sum, as a result of the sequential analysis conducted by Roland Barthes on an episode from the Bible, "Genesis 32: 22-32", the text revealed sequential breaks in the narrative. The resultant strategic ambiguity allowed for multiple interpretations to enter the narrative. Coming from other semiotic systems, these interpretations enhanced and transfigured the original text. Upholding the sequential unity, they have nonetheless changed the narrative design toward different metasemantic effects. The coupling of these effects produced a new semiotic montage. The effect of Rembrandt's painting put an emphasis on caress. Caress became the point of inflection for the narrative. Sir Jacob Epstein broadened the notion of caress in embrace. A sequential connection between caress and embrace identified the mode of giving the struggle between the Angel and Jacob - as an erotic encounter. By positioning the characters in a specific way, separating Jacob from the audience, yet connecting them by the directing gesture of the Angel, Chagall introduces a new element into the story: the connection between the Angel and his people generated a new way. By pointing to the people, the Angel speaks the sign. The sign is given in the face of the Angel. The semioethics of the encounter with the Angle is thus predicated on the meta-effects of caress, embrace, and face. In order to understand what the encounter means ethically, we need to engage yet another dimension, that of semioethics.

\section{Crossing Over with the Angel}

I associate semioethics with the name of Emmanuel Levinas who carried out a phenomenology of Eros in his major work, Totality and Infinity. Levinas (1969: 254) speaks about "erotic talk [...] interpreted as sensation", that is, the talk that represents the ethical domain. Understanding language as an ethical phenomenon means to approach the language of Eros in terms of love. For Levinas (1969: 260), love is the condition for the possibility of transcendence that "goes beyond the face." In its epiphany, the face of the other reveals the origin of exteriority appearing not as an image but as "the nudity of the principle" (Levinas 1969: 262). What is given by the nudity of the face is not a ritualized agon conducted in the aesthetic realm but the face-to-face relationship of love and responsibility grounded in ethics. From this formulaic, we might indeed see how the battle with the 
loving God who gives itself in the face of the Angel, the other, would override struggle aimed at overcoming with the passive embrace of becoming.

The ethics-first approach makes chastity and decency of the face "abide at the limit of the obscene yet repelled but already at hand and promising" (Levinas 1969: 263). The promise of the other makes Eros a social, albeit liminal phenomenon. At the same time, this liminality is not what delimits the whole, for then Eros will be at the service of the collective pleasure, a totality. Rather, the erotic nudity of the face designates "a way, the way of remaining in the no man's land between being and not-yet being" (Levinas 1969: 259, author's italics). Hence, the Angel's gift to Jacob: the way he shows is not the way Jacob can pursue on his own, but only by being connected to the divine face.

This characterization is essential, for it emphasizes the relation between Eros and ambiguity. For Levinas, ambiguity of Eros fuses the clandestine and its revelation in "the simultaneity or the equivocation of fragility and the weight of non-signifyingness, heavier than the weight of the formless real" (Levinas 1969: 257). The both/and of equivocation exposes the two sides of Eros: voluptuosity and fecundity. The relationship between the two sides is clearly asymmetrical, for the weight of responsibility in fecundity exceeds the fleeting enjoyment of voluptuosity. Because of the asymmetrical duality of the face-to-face relationship, the erotic, even in flight, and in tenderness, and vulnerability, cannot be hidden, only unseen, must remain unseen in order to be transcendence, the "what is not yet" (Levinas 1969: 256). This what is not yet is the mystery of love, and it can only reveal itself as mystery. Deprived of a particular form but tending toward the future, this mystery is without mystification: "the what is not yet is sensed in the night of the erotic, simultaneously uncovered by Eros and refusing Eros" (Levinas 1969: 258-259). In other words, the "what is not yet," the not-yet-sensible movement of erotic fecundity is unimaginable without the sensible enjoyment of voluptuosity.

The difference between the two co-joint modes is the difference of the self-other relation. While voluptuosity is a return to the self, fecundity is the very transcendence of the self. It is in fecundity that the face commands beyond refusal; there, it is more serious than serious. In apposition to voluptuosity, fecundity has the child for the other; it therefore "denotes my future" (Levinas 1969: 268). And not just the child; in addition to the offspring, who would stand for the 
past in the future, Levinas talks about paternity and filiality that extend my responsibility to a complete stranger, making his possibilities mine. The two modes of givenness are co-foundational: by abolishing any expression except for the refusal to express desire, voluptuosity clears the way for fecundity, which is already removed from the enjoyment of the other, and not just the other but, most importantly, from the enjoyment of the self. It is with this sign that Jacob, the Patriarch and the father of the Israeli people returns from his struggle to his people.

\section{References}

Agamben, Giorgio 2003. Remnants of Auschwitz. The Witness and the Archive. New York: Zone Books.

Barthes, Roland 1977. Image, Music, Text. London: Fontana Press.

Depraz, Natalie 2001. The Husserlian theory of intersubjectivity as alterology. Journal of Consciousness Studies 8(5/7): 169-178.

Derrida, Jacques 1992. Des tours de Babel. In: Schulte, Rainer; Biguenet, John (eds.), Theories of Translation. Chicago: The University of Chicago Press, 218-227.

Desroche, Henri 1973. Jacob and the Angel: An Essay in Sociologies of Religion. Amherst: University of Massachusetts Press.

Dickinson, Emily 1998. The Poems of Emily Dickinson: Variorum Edition. 3 vols. (Franklin, Ralph W., ed.) Cambridge: The Belknap Press of Harvard University Press.

Husserl, Edmund 1973. Zur Phänomenologie der Intersubjektivität. Texte aus dem Nachlass. Zweiter Teil: 1921-1928, Husserliana Vol. XIV. (Kern, Iso, ed.) The Hague: Martinus Nijhoff.

Levinas, Emmanuel 1969. Totality and Infinity. Pittsburgh: Duquesne University Press.

Singletery, Suzanne 2004. Jacob wrestling with the Angel: A theme in symbolist art. Nineteenth Century French Studies 32(3/4): 298-315.

Steinbock, Anthony 1995. Home and Beyond. Generative Phenomenology after Husserl. Evanston: Northwestern University Press.

Waldenfels, Bernhard 1996. Order in the Twilight. Athens: Ohio University Press.

- 1990. Experience of the Alien in Husserl's Phenomenology. Research in Phenomenology 20: 19-33.

- 1995. Svoya kultura i chuzhaya kultura: Paradoks nauki o 'chuzhom'. Logos 6: 77-94. 


\section{Переход с ангелом}

Эта статья является аналитическим развитием структурного анализа отрывка из Ветхого Завета (Книга Бытия 32: 22-32, известного как “Борьба с ангелом"), проведенного Роландом Бартом. Исследование отрывка в феноменологическом (ксенологическом) ключе как порогового явления, способствовало обнаружению в "Борьбе с ангелом" его “третьего смысла”, который проявляет себя на пересечении явного и скрытого. Анализ трех визуальных изображений отрывка из Книги Бытия 32: 22-32, а именно: "Борьба Иакова с ангелом" Рембрандта, “Иаков и ангел” сэра Джейкоба Эпстайна и "Иаков борется с ангелом” Марка Шагала, — также показывает, что “третьий смысл” базируется на основополагающей зависимости названия от изображения, указывающего на то, что “Борьба" должна пониматься как непосредственная взаимосвязь любви и ответственности, основанной на этических началах.

\section{Üleminek ingliga}

Artikkel on Roland Barthes'i poolt teostatud ühe Vana Testamendi katkendi (Esimene Moosese raamat 32: 22-32, tuntud kui "Võitlus ingliga") strukturaalanalüüsi analüütiliseks arenduseks. Selle katkendi vaatlemine piiripealse nähtusena fenomenoloogilises (ksenoloogilises) võtmes aitas kaasa "kolmanda tähenduse" avastamisele, mis ilmutab end avatud ja varjatu ristumispaigas. Selle katkendi kolme visuaalse representatsiooni (Rembrandti "Jaakobi võitlus ingliga", sir Jacob Epsteini "Jaakob ja ingel” ja Marc Chagalli "Jaakob võitleb ingliga") analüüs näitab samuti, et "kolmas tähendus" põhineb nimetuse alustpaneval sõltuvusel kujutisest, mis viitab sellele, et "Võitlust" tuleb siin mõista kui armastuse ja vastutuse vahetut seost, mis põhineb eetilistel alustel. 